\title{
Mercury Toxicity: Ecological Features of Organic Phase of Mercury in Biota- Part I
}

\author{
Loai Aljerf ${ }^{1 *}$ and Nuha AlMasri ${ }^{2}$ \\ ${ }^{1}$ Department of Basic Sciences, Damascus University, Syria \\ ${ }^{2}$ Department of Chemistry, Syrian Private University, Syria
}

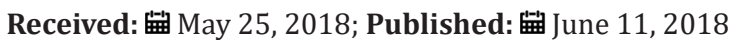

*Corresponding author: Loai Aljerf, Department of Basic Sciences, Faculty of Dental Medicine, Damascus University, Damascus, Syria, Tel: +96394448203, Email: envirochrom@hotmail.com

\begin{abstract}
Mercury is extensively used in industry with top usage in electrolytic chlorine. As a result of this elemental consumption in industry, different forms of inorganic and organic mercury get into the environment in great piles every day and many of these mercurial derivatives are converted to methylmercury by microorganisms. The study is assigned to inspect the ecological features of organic mercury species in biological and marine environments. In addition, the paper takes into account the uptake and the distribution of mercury in fish to investigate the conversion and mobilization of mercury from sediment deposits into the general environment. It has been confirmed that the biological half-life of methylmercury in human is about 70 days. In methodology, molecular identification of mercury has been defined. Monomethyl mercury in sediments was analyzed by gas chromatography (GC) hyphenated with electron capture detector (ECD) and the confirmation was measured by mass spectroscopy (MS). The conversion of mercury element to its organic species has been illustrated. In soil, it was found that lower pH favors monomethyl mercury and the higher $\mathrm{pH}$, dimethylmercury formation, respectively. Dimethylmercury is the biological poisoning product and methylmercury is an artifact of isolation procedure. In next paper, we will turn to study the epidemiological features of organic phase of mercury and investigate in deep the distribution, metabolism, and toxicity of mercury and methylmercury in some essential raw food materials, domestic animal feedstock, and some other biological specimens using basically simple analytical methods of chromatography as paper (PC) and thin layer (TLC).
\end{abstract}

Keywords: Industry; Mercurial derivatives; Microorganisms; Gas chromatography; Methylation rate

\section{Introduction}

The last two decades have dramatized the substantial toxicological significance of particularly methylmercury derivatives. Because the different forms of mercury which get into the environment are usually converted to methylmercury by microorganisms, it is illuminating to examine the sources and applications of mercurial derivatives, both of which are extensive. The world production of mercury in 2017 was estimated by 2500 metric tons [1]. Table 1 illustrates the areas of application, consumption, and percentage of use of mercury in the United States in 2005 [2], wherever, Table 2 lists the types of organic mercuric compounds used in agriculture alone. However, some reports mentioned that the uncontrolled or intentional discharge is believed to account for approximately 5000 tons of mercury per year to the environment [3]. This could be compared with 5000 tons per year of mercury transferred from the continents to the oceans by the rivers following continental weathering. Mercury in fossil fuels can reach values of approximately $0.5 \mathrm{ppm}$ [4]. The natural mercury levels in soils and water without industrial or agricultural contamination attains levels of approx. $0.02-0.04 \mathrm{ppm}$ for soils and $0.06 \mathrm{ppb}$ for water, respectively $[5,6]$.

Table 1: Consumption of mercury in the United States in 2005. Consumption based on 76 pound flasks

\begin{tabular}{|c|c|c|}
\hline Application & $\begin{array}{c}\text { Consumption (thousands of } \\
\text { pounds) }\end{array}$ & Use (\%) \\
\hline Electrolytic chlorine & 1572 & 26 \\
\hline Electrical apparatus & 1382 & 22.9 \\
\hline Paint & 739 & 12.1 \\
\hline Instruments & 391 & 6.5 \\
\hline Catalysts & 221 & 3.7 \\
\hline
\end{tabular}




\begin{tabular}{|c|c|c|}
\hline Dental preparations & 209 & 3.5 \\
\hline Agriculture & 204 & 3.4 \\
\hline $\begin{array}{c}\text { General laboratory } \\
\text { use }\end{array}$ & 126 & 2.1 \\
\hline Pharmaceuticals & 52 & 0.8 \\
\hline $\begin{array}{c}\text { Pulp and paper } \\
\text { making }\end{array}$ & 42 & 0.7 \\
\hline Amalgamation & 15 & 0.3 \\
\hline Other & 1082 & 18 \\
\hline Total & 6035 & 100 \\
\hline
\end{tabular}

variations [7]. Mercury is introduced into the ecosystem via agricultural uses, waste disposal (mercury used in seals in flow meters, underwater grinders and commutators in waste treatment plants), industrial catalyst effluents, incorporation into products (paints, pharmaceuticals, cosmetics), and accidental misuse as feeding of mercury-treated seeds to farm animals [8]. The adverse effects of mercurial pollution have been extensively reviewed and included:

a) Minamata, Japan [9], where a narcotizing disease of the central nervous system afflicting 3 people of whom 45 died during the period 2000 to 2013.

Table 2: Organicmercury compounds used in agriculture.

\begin{tabular}{|c|c|c|}
\hline Alkylmercury compounds & $\begin{array}{l}\text { Consumption } \\
\text { (thousands of } \\
\text { pounds) }\end{array}$ & Use (\%) \\
\hline $\begin{array}{c}\text { Methylmercuric sulfate, acetate, nitrile, } \\
\text { propionate, 8-hydroxyquinolate, } \\
\text { 2,3-dihydroxypropyl }\end{array}$ & 1572 & 26 \\
\hline $\begin{array}{c}\text { mercaptide, pentachlorophenolate, } \\
\text { p-chlorobenzoate, benzoate, } \\
\text { dicyandiamide }\end{array}$ & 1382 & 22.9 \\
\hline $\begin{array}{l}\text { N-Methylmercuric 1,2,3,6-tetrahydro- } \\
\text { 3,6-endomethano-3,4,5,6,7,7- } \\
\text { hexachlorophthalimide }\end{array}$ & 739 & 12.1 \\
\hline $\begin{array}{c}\text { Ethylmercuric silicate, chloride, } \\
\text { bromide, phosphate, acetone, urea, } \\
\text { oleate, stearate, pentachlorophenolate, } \\
\text { hydroxide, thiouronium } \\
\text { chloride, p-toluene sulfonamide, } \\
\text { 8-hydroxyquinolate, N-Ethylmercuric } \\
\text { 1,2,3.6-tetrahydro-3,6-endomethano- } \\
\text { 3,4,5,6,7,7-hexachlorophthalimide, } \\
\text { Ethyl phenethynylmercury, Mercury } \\
\text { pentanedione }\end{array}$ & 391 & 6.5 \\
\hline Alkyloxyalkylmercury compounds & 221 & 3.7 \\
\hline $\begin{array}{c}\text { Methoxyethylmercuric chloride, } \\
\text { silicate, dicyandiamide, benzoate, } \\
\text { lactate, acetate }\end{array}$ & 209 & 3.5 \\
\hline $\begin{array}{l}\text { Ethoxyethylmercuric chloride, silicate, } \\
\text { hydroxide }\end{array}$ & 204 & 3.4 \\
\hline $\begin{array}{l}\text { 1-Carboxy-3-ethoxyethylmercuric } \\
\text { propandicarboxylate }\end{array}$ & 126 & 2.1 \\
\hline Chloromethoxypropylmercuric acetate & 52 & 0.8 \\
\hline $\begin{array}{l}\text { p-(tert.-Octyl) phenoxyethoxyethyl } \\
\text { dimethylmercuric benzyl ammonium } \\
\text { chloride }\end{array}$ & 42 & 0.7 \\
\hline Arylmercury compounds & 15 & 0.3 \\
\hline $\begin{array}{l}\text { Phenylmercuric acetate, dimethyl } \\
\text { dithiocarbamate, chloride, dinaphthyl } \\
\text { methane sulfonate, }\end{array}$ & 1082 & 18 \\
\hline $\begin{array}{l}\text { urea, nitrate, iodide, benzoate, } \\
\text { pyrocatechinate, triethanol ammonium } \\
\text { lactate, 8-hydroxyquinolate, hydroxide, } \\
\text { lactate, oleate, propionate, salicylate, } \\
\text { salicylanilide, formamide, naphthenate }\end{array}$ & 6035 & 100 \\
\hline
\end{tabular}

b) Nigata, Japan, where 26 cases of mercury poisoning and 5 deaths have been documented [10].

The toxicity [11], bio-transformation [12] aspects of adsorption and distribution [13] of organomercurials have been described. The genetic effects of organomercurials include:

a. Mutagenicity of merthiolate in Drosophila melanogaster [14].

b. Mutagenic activity of Mercuran (fungicide containing 2\% ethylmercuric chloride and $12 \%$ hexachlorocyclohexane) in germinating apple seeds [15].

c. Somatic mutations produced by phenylmercuric hydroxide and phenylmercuric nitrate in flowering plants (seedlings of Raphanus and Zea) and induction of polyploid nuclei.

d. Sticky chromosome and chromosome fragments in root tips of Allium cepa [16]; cytological effects on root cells of Allium cepa of methylmercuric dicyandiamide, methylmercuric hydroxide, phenylmercuric hydroxide and methoxyethylmercuric chloride and the fungicide. Panogen (containing methylmercuric dicyandiamide as the active component) [17].

e. Cytological effects of inorganic, phenyl- and alkylmercuric compounds (e.g., phenylmercuric chloride, butylmercuric chloride and ethylmercuric chloride) on HeLa cell [18].

f. Histological and cytological effects of ethylmercuric phosphate in corn seedlings [19].

g. The C-mitotic action of "Granosan" (fungicide containing ethylmercuric chloride) [20].

h. Agrimax MS4 (containing ethylmercuric chloride and phenylmercuric dinaphthyl methanedisulfonate, respectively).

i. The genetic effects of methylmercuric hydroxide, phenylmercuric acetate and methoxyethylmercuric chloride in Drosophila melanogaster [21] and the induction of chromosome breakage in humans with methylmercury [22]. The complexing and denaturation of DNA by methylmercuric hydroxide has 
been reported [23]. The teratogenicity of phenylmercuric acetate in mice [24].

j. The embryotoxic effects of "methylmercury" in mice [25].

k. In humans the intrauterine effects of methylmercuric dicyandiamide in Denmark [26] and "methylmercury" in Japan [27] have also been described.

\section{Methyl Mercury}

\section{Ecological aspects}

As has been stated earlier, the different forms of mercury from various direct and indirect sources entering into the environment are converted to methylmercury. Wang et al. [28] described this conversion as shown in Scheme 1. Mercury in the first few centimeters $(2 \mathrm{~cm})$ of sediment (without microorganisms) is converted to the largest extent to methylmercury. In the next few centimeters in depth of sediment (with microorganisms) the highest rate of mercury methylation is achieved. The methylation rate is correlated with the microbiological activity in the sediment (e.g., higher rate of conversion at higher water temperature and increased amount of nutrients). It was also found that lower $\mathrm{pH}$ favors monomethyl mercury and the higher $\mathrm{pH}$, dimethylmercury formation, respectively.

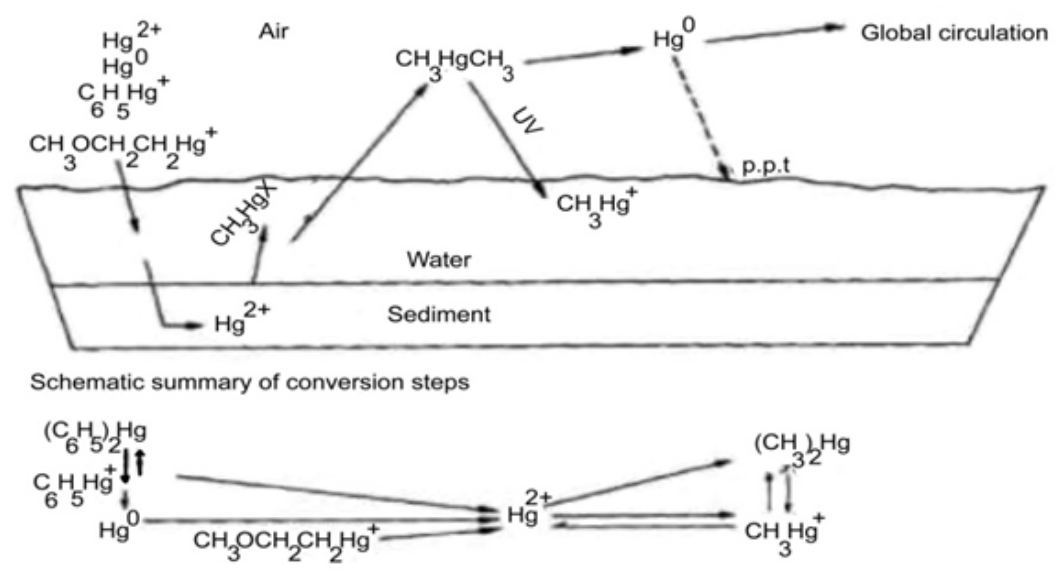

Figure 1: Conversion of mercury in the environment.

Figure 1 illustrates the conversion of metallic mercury to divalent mercury $\left(\mathrm{Hg}^{0} \mathrm{Hg}^{2+}\right)$ which has an affinity for organic mud. This binding for organic mud is extremely strong with a coefficient (the measure of the binding strength of a complex) greater than $10^{21}$ in comparison to other complexes. This conversion can occur under conditions present at the bottoms of lakes and rivers and has been shown to occur experimentally [29]. The conversion of divalent inorganic mercury to methylmercury $\left(\mathrm{Hg}^{2+} \mathrm{CH}_{3} \mathrm{Hg}^{+}\right.$and $\mathrm{CH}_{3} \mathrm{HgCH}_{3}$ ) has been shown to occur in bottom sediment from aquaria [30], and sediments from a large number of lakes and rivers have revealed microorganisms capable of methylating mercury [31]. The biological half-life of methylmercury in man has been calculated to be about 70 days [32], but its persistence in nature is believed to be much longer. Churchill et al. [33] have estimated that the effects of mercury pollution could last from 10 to 100 years unless control measures are instituted. The biological methylation of mercury in aquatic organisms has been described by Houserova et al. [29] who found that mono- and dimethylmercury $\left(\mathrm{CH}_{3} \mathrm{Hg}^{+}\right.$ and $\mathrm{CH}_{3} \mathrm{HgCH}_{3}$ ) can be produced in bottom sediments and in rotten fish. The same team has attributed the findings to the hazards of mercury pollution in Czech Republic.

\section{Methylmercury's synthesis}

The synthesis of methylmercury compounds by extracts of methanogenic bacterium has been described by Wood et al. [34].
The methanogenic organism (MOH) was isolated by Bryant et al. [35] from a symbiotic mixed culture obtained from canal mud at Delft, the Netherlands. Low concentrations of $\mathrm{Hg}^{2+}$ strongly inhibit methane formation, but the formation of $\mathrm{B}_{12}$-r from methyl cobalamin still proceeds and methylmercury and dimethylmercury are found as the sole reaction products by thin-layer chromatography $[36,37]$ or Purge and Trap GC in line with FTIR [38].

\section{Methylmercury chemical analysis}

Monomethylmercury was analyzed by conventional gas chromatographic [39] detection of $\mathrm{CH}_{3} \mathrm{HgX}$ (X=halogen) by means of an electron capture detector. Confirmation analyses were performed on an LKB 9000 gas chromatograph-mass spectrometer with the instrument set for detection of $\mathrm{m} / \mathrm{z}\left(\mathrm{CH}_{3}{ }^{200} \mathrm{Hg}^{2+}\right)$; the ionization potential was $20 \mathrm{eV}$. The $0.18 \times 180 \mathrm{~cm}$ column contained 10\% Carbowax 1500 on 60-80 mesh Chromosorb W and was maintained at $150^{\circ}$.

\section{Results and Discussion}

Figure 2 illustrates the concentration of methylmercury in bottom sediment after addition of inorganic mercury followed by incubation for 7 days. Figure 3 shows the concentration of methylmercury in bottom sediment after addition of 10 or 100 ppm of $\mathrm{HgCl}_{2}$ followed by variable times of incubation. The authors' demonstration of the biological methylation of mercury compounds 
provides an explanation for the fact that $\mathrm{CH}_{3} \mathrm{Hg}^{+}$is found in fish, even if all the known sources in the environment are in the form of inorganic mercury or phenylmercury and that the formation of the volatile dimethylmercury (bp $94^{\circ}$ ) may be a factor in the redistribution of mercury from aqueous industrial wastes. $\mathrm{CH}_{3} \mathrm{Hg}^{+}$ is soluble in water and is concentrated by living things, usually appearing in body lipids. In part, the concentration may arise by way of the food chain, but fish may also accumulate the toxic ion directly (the concentration factor from water to pike is of the order of 3000 or more). This basic study on the process of methylation appears to be of fundamental significance in the understanding of the uptake and distribution of mercury in fish and the conversion and mobilization of mercury from sediment deposits into the general environment.

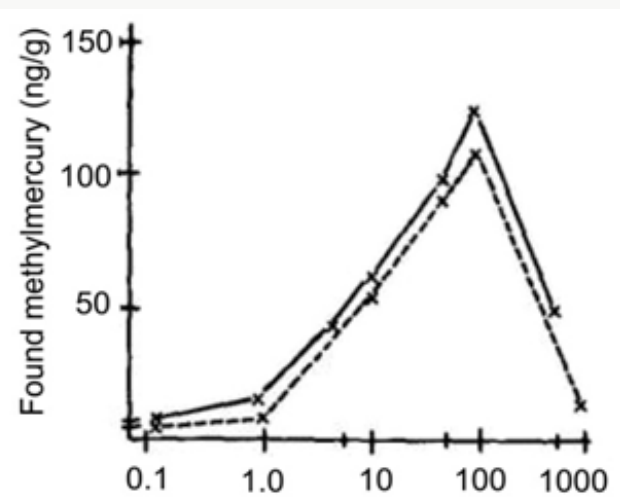

Figure 2: Concentration of methyl mercury in bottom sediment after addition of inorganic mercury followed by incubation for 7 days. Lines are drawn between mean values from five samples in two parallel experiment series.

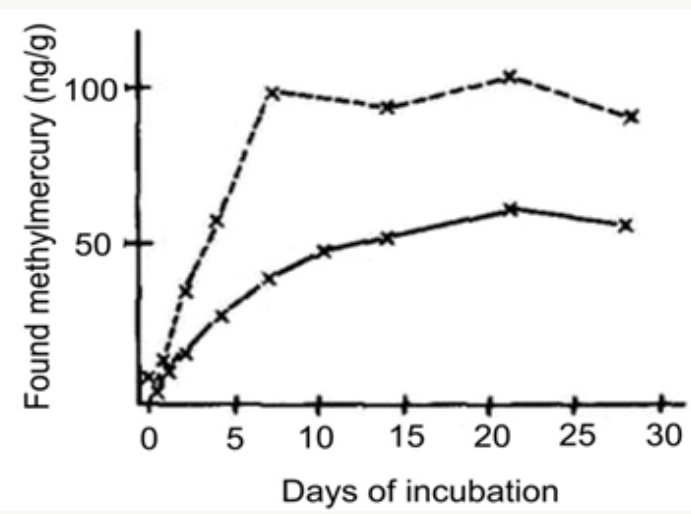

Figure 3: Concentration of methyl mercury in bottom sediment after addition of 10 or $100 \mathrm{ppm}$ of inorganic mercury followed by variable times of incubation. Lines drawn between mean values from five and three samples, respectively.

Methyl cobalamin ( $\mathrm{CH}_{3}$-Co-5, 6-dimethyl-benzimidazolyl cobalamin) was found to be an excellent substrate for the formation of methane in extracts of $\mathrm{MOH}$. The overall reaction required ATP, hydrogen as the source of electrons, and the prosthetic group of the enzyme has been shown to be factor III (R-Co-5OH- benzimidazolylcobamide) [34] (eqn. 1).

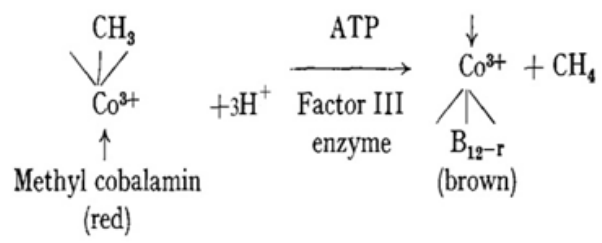

After deproteinization, the reaction products were extracted into diethylether, concentrated and subjected to TLC using lowboiling petroleum ether-diethylether (70:30) as developers. Spots were located with 4,4'-bis(dimethylamino)-thiobenzophenone and the $R_{F}$ values of methyl- and dimethylmercury were analogous to those previously reported by Babar and Shinde [36] and satisfied with outcomes of Huang et al. [40]. In order to elaborate whether methylmercury or dimethylmercury was the predominant reaction product, use was made of a general reaction of dialkylmercury compounds with acid, viz., R-Hg-R'+ $\mathrm{HCl} \mathrm{RH}+\mathrm{R}^{\prime}-\mathrm{HgCl}$. Thus, when hydrochloric acid was added to the standard reaction mixture containing $0.1 \mu$ mole of mercury originally as $\mathrm{Hg}^{2+}$, an additional $0.12 \mu$ moles of methane was evolved. (No additional methane was formed in control flasks lacking $\mathrm{Hg}^{2+}$, when acid was added.) Hence, these data indicate that dimethylmercury is the ultimate product of this methyl transfer reaction, although in reactions containing much higher levels of $\mathrm{Hg}^{2+}$, methylmercury is produced. Since acid precipitation of protein [41] is usually performed before the extraction of alkylmercury compounds into organic solvents [42]. It suggested the possibility that dimethylmercury could be the product of biological significance in mercury poisoning, and methylmercury could be an artifact of isolation procedure.

From our experience in this domain, we believe in the possible transfer of methyl groups from $\mathrm{Co}^{3+}$ to mercury in biological systems, may also occur as a non-enzymatic process. Hence, when methyl cobalamin and propyl cobalamin were allowed to react with two individual samples of $\mathrm{Hg}^{2+}$ under mild reducing conditions ( $\mathrm{Zn}$ dust plus ammonium chloride), the products of these reactions can be identified by TLC as methyl-, dimethyl, propyl-, and dipropyl mercury. The finding of apparent methyl transfer from $\mathrm{Co}^{3+}$ to $\mathrm{Hg}^{2+}$ in biological systems that may also occur as a non-enzymatic system has apparent significance from ecological considerations. Thus, if this methyl transfer reaction is significant in biological systems, then it could be enhanced by anaerobic conditions and by increasing numbers of bacteria capable of synthesizing alkyl cobalamins [43-45]. The authors suggest that pollution of a body of water with nutrients (sewage) will increase the rate of formation of methylmercury at a certain concentration of $\mathrm{Hg}^{2+}$. Methylmercury could be formed by both enzymatic and non-enzymatic reactions, hence making this cumulative poison available for incorporation into various organisms in the aquatic environment and secondarily terrestrial predators.

The action of a mercury-resistant strain of Pseudomonas on organic mercuricmercurials has been reported by Mortazavi and 
co-workers [46]. This organism was found capable of decomposing phenylmercuric acetate (PMA) into metallic mercury and benzene; ethylmercuric phosphate (EMP) into metallic mercury and ethane; and methylmercuric chloride (MMC) into metallic mercury and methanol [47]. More recently Mahbub et al. [48] described the decomposition of the organic mercurials, phenylmercuric acetate, ethylmercuric phosphate, and methylmercuric chloride by a cell-free extract of the same mercury-resistant Pseudomonas. In the current work, the cell-free extract was freshly prepared by ammonium sulfate fractionation of crude extract obtained from mechanically disrupted cells, treatment at $\mathrm{pH} \mathrm{5}$, and then dialysis. Benzene, ethane and methane were identified by GLC as the products from the decomposition of PMA, EMP and MMC, respectively (Table 3). The decomposition of PMA required the cellfree extract, glucose, NAD or NADP and thioglycolate (at an optimum pH of approx. 6). L-Cysteine, DL-homocysteine, reduced glutathione and mercaptoethanol could be substituted for thioglycolate. The decomposition of PMA also required thioglycolate in excess of its amount to form mercaptide in combination with PMA, and seemed to occur in conjunction with glucose dihydrogenase catalyzing the formation of reduced NAD or NADP. The decomposition of MMC by the cell-free extract was found to occur under analogous conditions found for PMA. The study meets with Tezuka and Tonomura [49] who used the cells of the K-62 strain of Pseudomonas aerobically incubated with ${ }^{203} \mathrm{Hg}$-labeled or [14C] phenyl-labeled PMA and indicated that about $70 \%$ of radioactive mercury or $80 \%$ of radioactive carbon disappeared from each medium in $2 \mathrm{~h}$ with the concomitant formation of metallic mercury and benzene as shown by GLC (Figure 4).

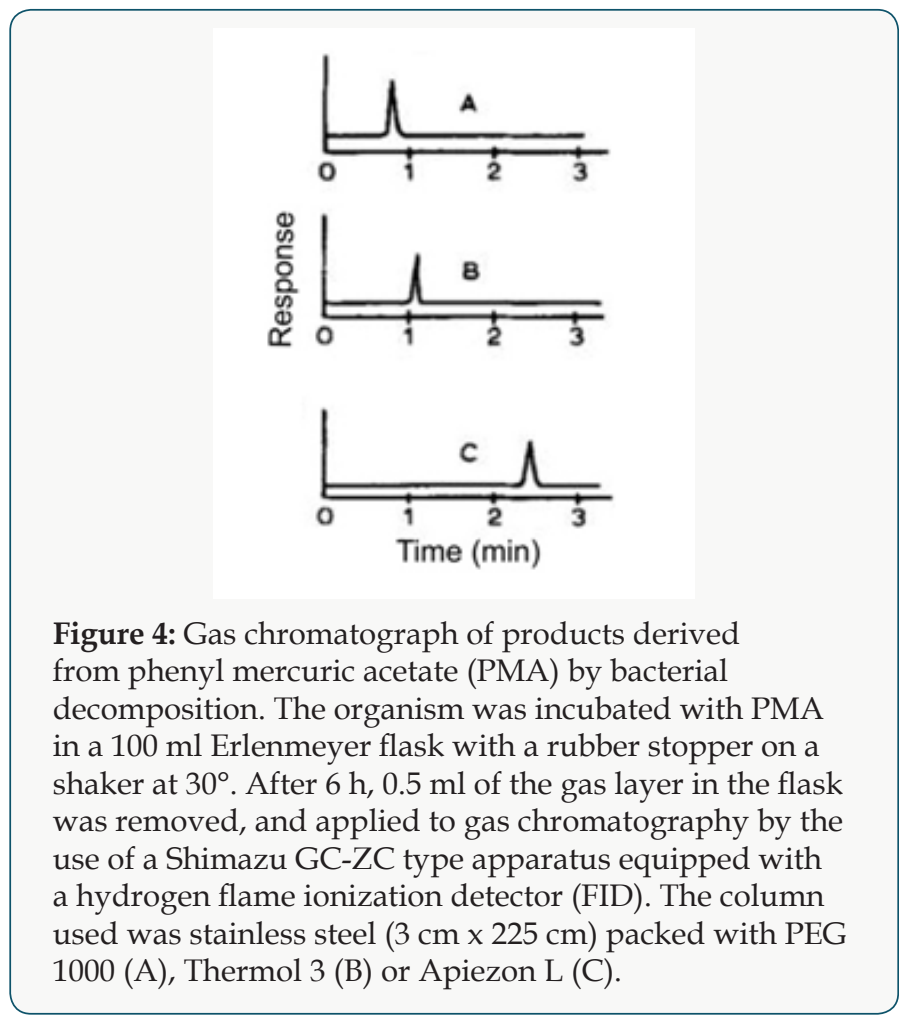

Table 3: Detection of products derived from decomposition of phenylmercuric acetate, ethylmercuric phosphate and methylmercuric chloride.

\begin{tabular}{|c|c|c|c|c|c|c|}
\hline & PMA & & EMP & & MMC & \\
\hline & With extract & Without extract & With extract & Without extract & With extract & Without extract \\
\hline $\begin{array}{c}\text { Gas } \\
\text { chromatography }\end{array}$ & Benzene & None & Ethane & None & Methane & None \\
\hline $\begin{array}{l}\text { Detector tube for } \\
\text { mercury containing }\end{array}$ & \multirow[t]{2}{*}{+} & \multirow[t]{2}{*}{-} & \multirow[t]{2}{*}{+} & \multirow[t]{2}{*}{-} & \multirow[t]{2}{*}{+} & \multirow[t]{2}{*}{-} \\
\hline cuprous iodide & & & & & & \\
\hline
\end{tabular}

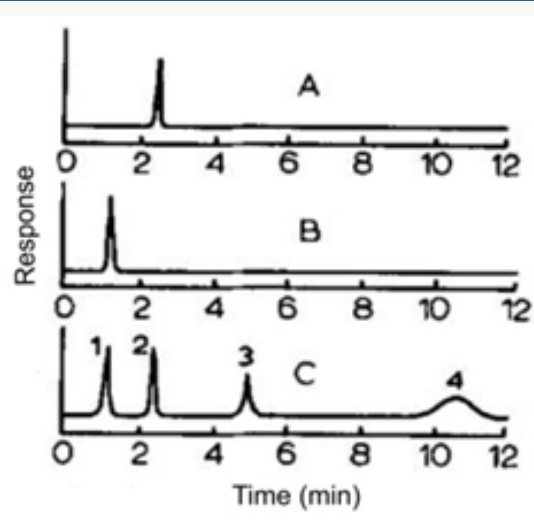

Figure 5: Gas chromatograms of products derived from ethylmercuric phosphate (EMP) and methyl mercuric chloride (MMC) by bacterial decomposition. The column used was stainless steel $(3 \mathrm{~cm} \times 150 \mathrm{~cm})$ packed with silica gel. (A) Decomposed product of EMP; (B) Decomposed product of MMC; (C) Authentic reagents: (1) Methane, (2) Ethane, (3) Ethylene, (4) Propane and butane. 
The organism was incubated with PMA in a $100 \mathrm{ml}$ Erlenmeyer flask with a rubber stopper on a shaker at $30^{\circ}$. After $6 \mathrm{~h}, 0.5 \mathrm{ml}$ of the gas layer in the flask was removed, and applied to gas chromatography by the use of a Shimazu GC-ZC type apparatus equipped with a hydrogen flame ionization detector (FID). The column used was stainless steel $(3 \mathrm{~cm} \times 225 \mathrm{~cm})$ packed with PEG 1000 (A), Thermol 3 (B) or Apiezon L (C). In additional experiments with ethylmercuric phosphate and methylmercuric chloride, metallic mercury, ethane, and methane, respectively, were found as a result of analogous bacterial decomposition (Figure 5).

A hypothetical scheme for the decomposition of phenylmercuric acetate via cleavage of the mercury-carbon bond by a cell-free extract of a mercury-resistant strain of Pseudomonas was suggested by Tezuka and Tonomura [49] as illustrated in Figure 6. It is of interest to note that the vaporization of ${ }^{203} \mathrm{Hg}$-labeled mercuric chloride by cell-free extracts of drug-resistant Escherichia coli required NADPH and a magnesium ion for maximal vaporization of ${ }^{203} \mathrm{Hg}$ while NADH had only a slight stimulation effect [50]. Since NADPH rather than NADP ions appears essential for the reaction, reduction of mercuric chloride comes out to be necessary for the vaporization of mercury. Cell-free extracts from the sensitive strain have not any vaporizing activity of ${ }^{203} \mathrm{Hg}$. Chasanah et al. [51] have also reported the reduction of mercuric chloride by mercuryresistant bacteria isolated from air. Ghosh et al. [52] studied the volatilization of mercury from various biological media (e.g., tissue homogenates, infusion broth, plasma and urine) containing mercury as ${ }^{203} \mathrm{HgCl}_{2}$ and found Pseudomonas aeruginosa, Protens spp., and two more unidentified microorganisms present in the water supply that could convert mercuric ion to elemental mercury.

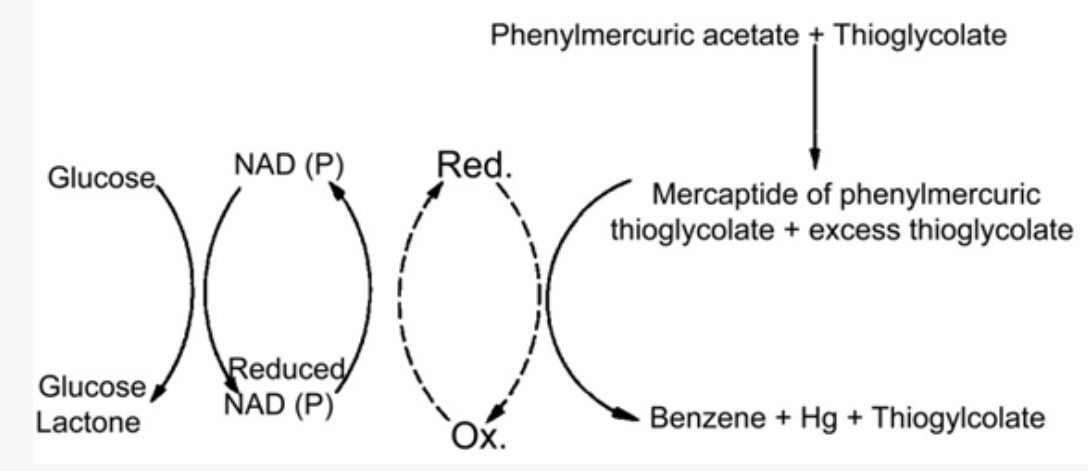

Figure 6: Hypothetical scheme proposed for the decomposition of phenylmercuric acetate by cell free extract of a mercury resistant strain of Pseudomonas (adapted from Tezuka and Tonomura [49]).

\section{Conclusion}

Water pollution with nutrients (sewage) increases the formation of methyl mercury. $\mathrm{CH}_{3} \mathrm{Hg}^{+}$is found in fish, even if all the known sources in the environment are in the form of inorganic mercury or phenylmercury and that the formation of the volatile may be a factor in the redistribution of mercury from aqueous industrial wastes.

\section{References}

1. A Scott (2017) EU's chlorine makers end mercury based production C\&EN Global Enterprise 95(49): 13-13.

2. PA Maxson (2005) Global Mercury Production, Use and Trade. In: N Pirrone, KR Mahaffey (eds) Dynamics of Mercury Pollution on Regional and Global Scales, Springer, Boston, MA, US pp 25-50.

3. Y Sequeira León, I Luna Avilés, J Huete Peréz (2017) Mercury pollution in La Libertad, a gold mining town in Central Nicaragua. Uncontrolled mining, economic crisis, and climate effects-A dangerous mixture. Epidemiology 22(1): 291-292.

4. AABM Azoddein, RBM Yunus, NMBN Sulaiman, ABB Bustary, FABM Azli, et al. (2017) Effect of Mercury concentration on P putida growth in Mercury removal. Journal of Applied and Physical Sciences 3(3).

5. M Urík, M Hlodák, P Mikušová, P Matúš (2014) Potential of microscopic fungi isolated from mercury contaminated soils to accumulate and volatilize mercury (II). Water, Air, \& Soil Pollution 225(12): pp2219.
6. L Aljerf, AE Choukaife (2018) Review: Assessment of the doable utilisation of dendrochronology as an element tracer technology in soils artificially contaminated with heavy metals. Biodiversity International Journal 2(1): 1-8.

7. X Fu, X Feng, R Yin, H Zhang (2014) Diurnal variations of total mercury, reactive mercury, and dissolved gaseous mercury concentrations and water/air mercury flux in warm and cold seasons from freshwaters of southwestern China. Environmental Toxicology and Chemistry 32(10): 2256-2265.

8. L Aljerf, N AlMasri (2018) In modern ocular pharmacologydexamethasone the top active corticosteroid. EC Pharmacology and Toxicology 6(6): 463-468.

9. J Templeton, P Kohler (2014) Implementation and compliance under the Minamata Convention on mercury. Review of European, Comparative \& International Environmental Law 23(2): 211-220.

10. M Sakata, K Asakura (2008) Evaluating relative contribution of atmospheric mercury species to mercury dry deposition in Japan. Water, Air, and Soil Pollution 193(1-4): 51-63.

11. MC Houston (2011) Role of mercury toxicity in hypertension, cardiovascular disease, and stroke. The Journal of Clinical Hypertension 13(8): 621-627.

12. JCJ Bonzongo, BW Nemer, WB Lyons (2006) Hydrologic controls on water chemistry and mercury biotransformation in a closed river system: The Carson River, Nevada. Applied Geochemistry 21(11): 1999-2009.

13. AM Mota, MLS Gonçalves, JP Farinha, J Buffle (1994) Adsorption of poly (ethylene glycol)s on mercury/aqueous solution interface 1. Kinetics 
of PEG 8000 adsorption. Colloids and Surfaces A: Physicochemical and Engineering Aspects 90(2-3): 271-278.

14. M Sorsa, S Pfeifer (2009) Response of puffing pattern to in vivo treatments with organomercurials in Drosophilamelanogaster. Hereditas 74(1): 89102.

15. R Lekevichus, T Vijanskaja, R Stukiene (1978) Mutagenic activity of ethylmercurichloride and its disintegration product mercury. Mutation Research/Environmental Mutagenesis and Related Subjects 53(2): 218219.

16. HA Gadhavi, H Pandya (2017) Phytochemical Screening of Antimicrobials from Allium cepa. International Journal of Science and Research 6(7): 1499-1501.

17. FC Wright, JS Palmer, JC Riner (1973) Accumulation of mercury in tissues of cattle, sheep, and chickens given the mercurial fungicide, Panogen 15, orally. Journal of Agricultural and Food Chemistry 21(3): 414-416.

18. SM Mcguinness, DA Roess, BG Barisas (1990) Acute toxicity effects of mercury and other heavy metals on HeLa cells and human lymphocytes evaluated via microcalorimetry. Thermochimica Acta 172: 131-145.

19. XZhao, D Wang (1990) Mercury in some chemical fertilizers and the effect of calcium superphosphate on mercury uptake by corn seedlings (Zea mays L.). Journal of Environmental Sciences 22(8): 1184-1188.

20. JR Booer (1951) The action of mercury as a soil fungicide. Annals of Applied Biology 38(2): 334-347.

21. C Pirker, T Möslinger, F Wantke, M Götz, R Jakrisch (1993) Ethylmercuric chloride: the responsible agent in thimerosal hypersensitivity. Contact Dermatitis 29(3): 152-154.

22. R Kato (1976) Chromosome breakage associated with organic mercury in Chinese hamster cells in vitro. Mutation Research/Environmental Mutagenesis and Related Subjects 38(5): 340-341.

23. DW Gruenwedel, N Davidson (1967) Complexing and denaturation of DNA by methylmereuric hydroxide. II. Ultracentrifugation studies. Biopolymers 5(9): 847-861.

24. T Suzuki, N Matsumoto, T Miyama, H Katsunuma (1967) Placental transfer of mercuric chloride, phenyl mercury acetate and ethyl mercury acetate in mice. Industrial Health 5(2): 149-155.

25. TF Gale (1984) The amelioration of mercury-induced embryotoxic effects by simultaneous treatment with zinc. Environmental Research 35(2): 405-412.

26. P Grandjean, P Weihe (1993) Neurobehavioral effects of intrauterine mercury exposure: potential sources of bias. Environmental Research 61(1): 176-183.

27. N Ishihara (2017) Turning points in methylmercury poisoning episode in Japan (Minamata disease). Trace Elements and Electrolytes 34(2): 8487.

28. D Wang, L He, S Wei, X Feng (2006) Estimation of mercury emission from different sources to atmosphere in Chongqing, China. Science of The Total Environment 366(2-3): 722-728.

29. P Houserova, V Kuban, P Spurny, P Habarta (2012) Determination of total mercury and mercury species in fish and aquatic ecosystems of Moravian rivers. Veterinární Medicína 51(3): 101-110.

30. B Inza, F Ribeyre, A Boudou (1998) Dynamics of cadmium and mercury compounds (inorganic mercury or methylmercury): uptake and depuration in Corbicula fluminea. Effects of temperature and pH. Aquatic Toxicology 43(4): 273-285.

31. H Hsu-Kim, KH Kucharzyk, T Zhang, MA Deshusses (2013) Mechanisms regulating mercury bioavailability for methylating microorganisms in the aquatic environment: A Critical Review. Environmental Science \& Technology 47(6): 2441-2456.

32. L Magos (1975) Variation of biological half-life of methylmercury in man. Archives of Environmental Health: An International Journal 28(4): 371371.

33. RC Churchill, CE Meathrel, PJ Suter (2004) A retrospective assessment of gold mining in the Reedy Creek sub-catchment, northeast Victoria, Australia: residual mercury contamination 100 years later. Environmental Pollution 132(2): 355-363.

34.JM Wood, FS Kennedy, CG Rosen (1968) Synthesis of methylmercury compounds by extracts of a methanogenic bacterium. Nature 220(5163): 173-174.

35. MP Bryant, EA Wolin, MJ Wolin, RS Wolfe (1967) Methanobacillus omelianskii, a symbiotic association of two species of bacteria. Archiv für Mikrobiologie 59(1-3): 20-31.

36. VJ Babar, VM Shinde (1981) Thin Layer Chromatographic separation of copper and mercury chelates. Journal of Liquid Chromatography 4(5): 841-847.

37. L Aljerf, AE Choukaife (2017) A novel method to chromatographically resolution of sulphonamides by vapour-programmed Thin-Layer Chromatography. MOJ Bioorganic \& Organic Chemistry 1(4): 00024.

38. M Fillippelli, F Baldi (2010) ChemInform Abstract: Alkylation of ionic mercury to methylmercury and dimethylmercury by methylcobalamin: simultaneous determination by Purge and Trap GC in line with FTIR. ChemInform 25(20).

39. L Aljerf, K Beasley, B Smith, N Ganeshan (2017) Glass chromatography application: TLC separation of benzoic esters in pharmaceutical products. International Journal of Biochemistry Advances 1(1): 1-8.

40. H Huang, L Huang, P Xia (2016) Simultaneous determination of methylmercury and inorganic arsenics in aquatic products by gas chromatography-mass spectrometry with aqueous derivatization. Chinese Journal of Chromatography 34(9): 918-924.

41. L Aljerf, N AlMasri (2018) High resolution chromatography and sensitive retention: optimization of the experimental conditions for proteins extraction by preparative HPLC. Journal of Progressive Research in Modern Physics and Chemistry 3(1): 97-103.

42.J Hu, E Pagliano, X Hou, C Zheng, L Yang, et al. (2017) Sub-ppt determination of butyltins, methylmercury and inorganic mercury in natural waters by dynamic headspace in-tube extraction and GC-ICPMS detection. Journal of Analytical Atomic Spectrometry 32(12): 24472454 .

43. Y Wang, T Robison, H Wiatrowski (2013) The impact of ionic mercury on antioxidant defenses in two mercury sensitive anaerobic bacteria. BioMetals 26(6): 1023-1031.

44. L Aljerf (2015) Fabrication et test d'un catalyseur d'acide sulfonique approprié pour la réaction de production des biocarburants. Afrique SCIENCE 11(6): 349-358.

45. L Aljerf (2016) Méthode de synthèse économique et environnementale de la cardolite alkylée. American Journal of Innovative Research and Applied Sciences 3(1): 415-422.

46.S Mortazavi, A Rezaee, A Khavanin, S Varmazyar, M Jafarzadeh (2005) Removal of mercuric chloride by a mercury resistant pseudomonas putida strain. Journal of Biological Sciences 5(3): 269-273.

47. S Tariq (2015) PCR based DNA fingerprinting of mercury resistant and nitrogen fixing Pseudomonas spp. Pure and Applied Biology 4(1): 129136. 
48. KR Mahbub, KKrishnan, RNaidu, MMegharaj(2017) Mercury remediation potential of a mercury resistant strain Sphingopyxis sp. SE2 isolated from contaminated soil. Journal of Environmental Sciences 51: 128-137.

49. T Tezuka, K Tonomura (1976) Purification and properties of an enzyme catalyzing the splitting of carbon-mercury linkages from mercuryresistant pseudomonas K-62 strain. The Journal of Biochemistry 80(1): 79-87.

50. F Kafilzadeh, Y Zahirian, H Zolgharnein (2013) Isolation and molecular identification of mercury resistant bacteria and detection of Escherichia coli mercuric reductase gene from wastewater of Khowre-Musa, Iran. International Journal of Biosciences 3(8): 313-318.

51. U Chasanah, Y Nuraini, E Handayanto (2018) The potential of mercuryresistant bacteria isolated from small-scale gold mine tailings for accumulation of mercury. Journal of Ecological Engineering 19(2): 236245 .

52.S Ghosh, PC Sadhukhan, J Chaudhuri, DK Ghosh, A Mandal (1996) Volatilization of mercury by immobilized mercury-resistant bacterial cells. Journal of Applied Bacteriology 81(1): 104-108.

\section{Cc) \\ This work is licensed under Creative Commons Attribution 4.0 License}

To Submit Your Article Click Here:

$\underline{\text { Submit Article }}$

DOI: 10.32474/AOICS.2018.03.000157

\section{AOICS}

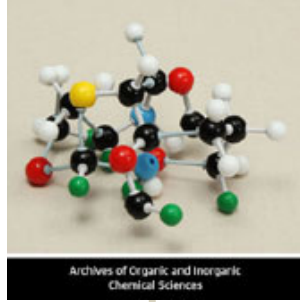

Archives of Organic and Inorganic Chemical Sciences

\section{Assets of Publishing with us}

- Global archiving of articles

- Immediate, unrestricted online access

- Rigorous Peer Review Process

- Authors Retain Copyrights

- Unique DOI for all articles 